\section{US 'openness' bill is counterproductive}

The US 2015 Secret Science Reform Act puts transparency in environmental science under the spotlight (D. Sarewitz Nature 525, 159; 2015). But the bill could end up weakening, rather than strengthening, environmental laws.

Of course, whatever scientific data can be made public should be. However, the bill as written will prevent agencies from using the best available science to protect public health. It stipulates that the US Environmental Protection Agency (EPA) should adopt new rules only after making raw data on pollution — including its effects on individuals - publicly available. The catch-22 is that the agency is rightly prohibited from revealing any such information that is confidential.

The EPA and scientific organizations have repeatedly raised these concerns, but the bill's sponsors have not addressed them. I agree with critics who conclude that its real intention could be to weaken environmental laws. Those politicians who hide their policy preferences behind scientific arguments must be held accountable.

Andrew A. Rosenberg Union of Concerned Scientists, Cambridge, Massachusetts, USA.

arosenberg@ucsusa.org

\section{Community initiative tackles urban heat}

A community-driven initiative is amassing data on urban form and function to help cities worldwide to develop their own heat-adaptation plans (see Nature 524, 402-404; 2015). It is called the World Urban Database and Access Portal Tools (WUDAPT; www.wudapt.org).

Urban experts use freely available Landsat satellite imagery to create and study local climate zones across their city (see also B. Wake Nature Clim. Change 2, 487; 2012). Citizen scientists gather information on building materials and function, landscape morphology and vegetation types.

These extensive open-access WUDAPT data will provide a standardized characterization of the world's major cities and detailed input data for urban climate models. City planners and climate modellers will be equipped with accurate boundary conditions for investigating a range of mitigation and adaptation scenarios. Other applications include modelling the effects of changes to the energy infrastructure and improving the assessment of greenhouse-gas emissions through better calculations. Linda See International Institute for Applied Systems Analysis, Laxenburg, Austria.

Gerald Mills University College Dublin, Ireland.

Jason Ching University of North Carolina, Chapel Hill, USA. see@iiasa.ac.at

\section{New oil investments boost carbon lock-in}

Bringing new oil supplies to market could have an unexpectedly large impact on global emissions (see P. Erickson and M. Lazarus Nature Clim. Change 4, 778-781; 2014). New sources of oil increase carbon dioxide emissions in the short term, and make it harder and more expensive to scale down production in the long term. This 'carbon lock-in' entrenches our dependence on fossil fuels and commits economies to higher emissions (see go.nature. com/djtala).

The scale of investment in oil supplies and the profits they bring over the long term already dwarf those associated with other fuels. And significant barriers still confront the adoption of competing low-carbon technologies, such as electric vehicles. Capital-intensive oil fields that have low operating costs relative to oil prices - as with most offshore oil deposits - make it even harder for us to switch. To wean us off oil, world leaders urgently need to curtail the billions of dollars that are currently earmarked for oil exploration and extraction.

Peter Erickson, Michael

Lazarus Stockholm Environment Institute, Seattle, Washington, USA.

pete.erickson@sei-us.org

\section{Ban unfair pricing of equipment imports}

We believe that imported scientific equipment should be more fairly priced for researchers in China. We can be charged up to three times more than our counterparts in Western laboratories. By contrast, price differences for imported equipment are insignificant for scientists in Japan and Australia.

Examples of overpriced equipment include lasers for measuring distance, Doppler ultrasonic flow meters, data loggers and soil- or waterrelated sensors. Many of China's researchers are currently forced to spend as much as $60 \%$ of their funding on foreign equipment.

Our informal consultations with researchers and sales representatives suggest that prices in the Chinese market are inflated by distributors' charges and service fees, deals between distributors and manufacturers, and for other unknown reasons. Shipping fees account for only a small proportion of the surcharge.

To further its research and development, China needs to introduce more powerful regulations against these pricing monopolies. It should also step up its own manufacturing capability of key scientific equipment.

Rengui Jiang Xian University of Technology, Xian, China.

jrengui@163.com

\section{Continental-drift opus turns 100}

One hundred years ago this year, the legendary German explorer, geophysicist and meteorologist Alfred Wegener published his milestone book The Origin of Continents and Oceans (see Nature 127, 861; 1931). His theory of continental drift was initially viewed as heresy by the scientific community, yet his book was later translated into many languages and updated regularly until 1929.

For his opus, Wegener assembled an array of geological, palaeontological and geophysical data. They are best explained, he argued, by hypothesizing that major landmasses eventually broke apart and went their separate ways. After his death, his ideas were largely forgotten until the 1960s, when geophysicists demonstrated the phenomenon of sea-floor spreading (see N. Oreskes Nature 501, 27-29; 2013). Plate tectonics has since gained acceptance as a synthetic theory with huge explanatory power.

Wegener died in 1930 while exploring in Greenland. Buried in the ice, his body has sailed westwards at a rate of about 2 centimetres per year on the back of the North American plate. He would have been glad to know that it will have travelled some 20 kilometres in a million years' time - in accordance with his visionary theory. Marco Romano Sapienza University of Rome, Italy. Richard L. Cifelli Sam Noble Oklahoma Museum of Natural History, Norman, Oklahoma, USA. rich.cifelli@gmail.com

\section{CONTRIBUTIONS}

Correspondence may be submitted to correspondence@nature. com after consulting the author guidelines at http:// go.nature.com/cmchno. 